\title{
PENINGKATAN KEAKTIFAN DAN HASIL BELAJAR PESERTA DIDIK DALAM PEMBELAJARAN PPKn MELALUI PENDEKATAN ADIK SIMBA BERBASIS GERAI INFORMASI
}

\author{
Agustinus Sugeng Priyanto ${ }^{1}$, Andi Suhardiyanto ${ }^{2}$, Isriadi Wijiastuti ${ }^{3}$
}

\begin{abstract}
Abstrak: Tujuan penelitian adalah mengetahui pelaksanaan pembelajaran dan dampak peningkatan aktivitas dan prestasi hasil belajar melalui pendekatan adik simba berbasis gerai informasi pada materi Pancasila Sebagai Dasar Negara dan Pandangan Hidup Bangsa dalam meningkatkan aktivitas dan prestasi belajar di kelas VIII F Sekolah Menengah Pertama Negeri 40 Kota Semarang. Pendekatan penelitian ini adalah penelitian tindakan kelas dengan metode pengambilan data melalui observasi, wawancara dan dokumentasi. Penelitian ini dilaksanakan dalam 2 siklus. Hasil penelitian menunjukkan bahwa pelaksanaan pembelajaran dengan pendekatan adik simba berbasis gerai dapat meningkatkan aktivitas belajar dan prestasi hasil belajar. Dampak peningkatan aktivitas belajar dan prestasi hasil belajar ditunjukkan dengan tingkat keaktifan dalam mengikuti proses pembelajaran sudah menunjukkan pada skala tinggi. Suasana kelas dinamis dan kondusif. Sebagian besar peserta didik aktif dalam pembelajaran dalam menyelesaikan tugas secara berkelompok walaupun masih ada beberapa peserta didik belum aktif. Ketuntasan belajar sudah mencapai $97 \%$ artinya indikator kinerja penelitiansudah tercapai.
\end{abstract}

Kata Kunci: Aktifitas;Prestasi: Adik Simba; Gerai informasi

\section{PENDAHULUAN}

Guru sebagai tenaga profesional mempunyai tiga peran utama dalam meningkatkan kualitas pembelajaran di kelas. Tiga peran utama guru yaitu peran sebagai perencana program pembelajaran, peran sebagai pengelola pembelajaran dan peran sebagai penilai keberhasilan belajar peserta didik. Sebagai perencana program pembelajaran guru bertanggung jawab dalam menyusun dan merumuskan program pembelajaran baik dalam bentuk silabus dan rencana pelaksanaan pembelajaran.

Peserta didik dalam proses
pembelajaran akan lebih mudah
membangun pemahaman apabila dapat
mengkomunikasikan gagasannya kepada
peserta didik lainnya atau guru.
Membangun pemahaman akan lebih

mudah melalui interaksi dengan lingkungan sosialnya. Interaksi memungkinkan terjadinya perbaikan terhadap pemahaman peserta didik melalui diskusi, saling bertanya, dan saling menjelaskan. Interaksi dapat ditingkatkan dengan belajar kelompok. Penyampaian gagasan oleh peserta didik dapat mempertajam, memperdalam, memantapkan, atau menyempurnakan gagasan itu karena memperoleh tanggapan dari peserta didik lain atau guru.

Dalam implementasinya, pelaksanaan proses pembelajaran di kelas masih banyak yang mengikuti pola lama, yaitu berpusat pada guru. Guru mengajarkan peserta didik dengan menggunakan materi yang dituangkan di dalam rencana pembelajaran dengan metode yang dipakai pada umumnya bersifat konvensional 
(tatap muka atau ceramah). Proses pembelajaran diharapkan berjalan lancar

tanpa memperhatikan perbedaanperbedaan individual peserta didik seperti cara belajar, intelegensi, motivasi, dan minat, serta kesulitan-kesulitan yang mungkin dihadapi oleh mereka.

Berdasarkan hasil pengamatan pelaksanaan kegiatan proses pembelajaran di kelas yang telah berlangsung selama ini, kondisi yang ditemui guru antara lain motivasi peserta didik dalam mengikuti pembelajaran di kelas masih rendah hal ini ditunjukkan dengan kondisi dimana banyak peserta didik yang tidak fokus

dalam mengikuti pembelajaran , kecenderungan tidak semangat, malas, minat membaca dan belajar kurang, bahkan terlihat acuh tak acuh dengan melakukan aktivitas yang tidak ada kaitannya dengan pembelajaran. Peserta didik yang aktif hanya tertentu saja dan jumlahnya sebagian kecil. Kondisi ini ternyata berpengaruh kepada pencapaian prestasi akademik peserta didik. Hasil tes prestasi belajar menunjukkan bahwa ketuntasan belajar yang masih dibawah $80 \%$ dari jumlah peserta didik.

Kondisi di atas menunjukkan bahwa ada dua kendala yang dihadapi guru dalam pelaksanaan kegiatan proses pembelajaran di kelas yaitu kurangnya minat dan semangat belajar peserta didik dan tingkat pencapaian prestasi hasil pembelajaran. Kurangnya minat peserta didik dalam pembelajaran disebabkan karena pelaksanaan kegiatan pembelajaran yang dilakukan belum secara optimal menitik beratkan pada aktivitas belajar peserta. Pembelajaran berbasis literasi merupakan salah satu upaya untuk menumbuhkan semangat belajar peserta didik.

Salah satu strategi pembelajaran yang dapat digunakan dalam literasi adalah Adik Simba. Adisk simba adalah pendekatan pembelajaran dimana peserta didik diberikan pengalaman untuk mengidentifikasi informasi penting dengan menggunakan kata tanya. Kata tanya yang digunakan antara lain siapa, apa, kapan, dimana, mengapa, bagaimana. Pada pendekatan pembelajaran adik simba, peserta didik diminta untuk menganalisis materi pembelajaran dengan kata tanya 5W1H (What, Who, Where, When, Why, How).

Berdasarkan kondisi di atas, untuk mengatasi permasalahan yang di hadapi terkait dengan meningkatkan motivasi belajar dan prestasi hasil belajar peneliti akan melakukan penelitian tindakan kelas dengan Materi Pancasila Sebagai Dasar Negara Dan Pandangan Hidup Bangsa Melalui Pendekatan Adik Simba Berbasis Gerai Informasi Di Kelas VIII F SMP N 40 Kota Semarang

\section{METODE PENELITIAN}

Metode yang digunakan dalam penelitian ini adalah penelitian tindakan kelas. Metode yang digunakan adalah penelitian tindakan kelas (Classroom Action Research), yang menempatkan posisi peneliti bukan sekedar memecahkan masalah pembelajaran yang ada di dalam kelas namun juga merefleksikan secara kritis dan kolaboratif suatu implementasi rencana pembelajaran. Rencana yang ditetapkan dalam Penelitian Tindakan Kelas menurut Kemmis. Dan Mc. Taggart

(Suharsimi Arikunto,

1997:84) 
menggunakan 2 siklus, masing-masing siklus terdiri dari perencanaan, palaksanaan tindakan, observasi dan refleksi. Menurut Kurt Lewin, prosedur kerja dalam penelitian tindakan kelas terdiri atas empat komponen, yaitu perencanaan (planning), pelaksanaan (acting), pengamatan (observing), dan refleksi (reflecting). Penelitian tindakan kelas ini dilaksanakan selama 2 siklus (sesuai dengan kebutuhan) dalam proses perkuliahan. Setiap siklus terdiri dari 4 tahapan, yaitu perencanaan, pelaksanaan tindakan, observasi, evaluasi dan refleksi. Siklus 2 dilakasanakan jika pada siklus 1 belum diperoleh hasil sebagaimana indikator keberhasilan, maka tindakan diperbaiki pada siklus selanjutnya, demikian seterusnya.
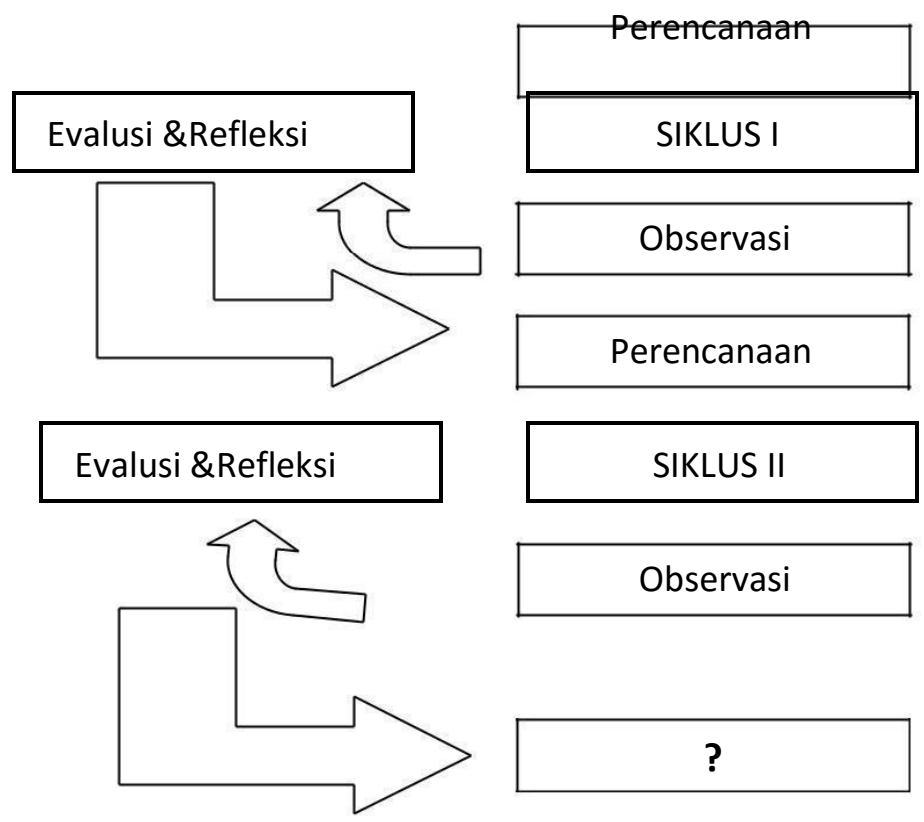

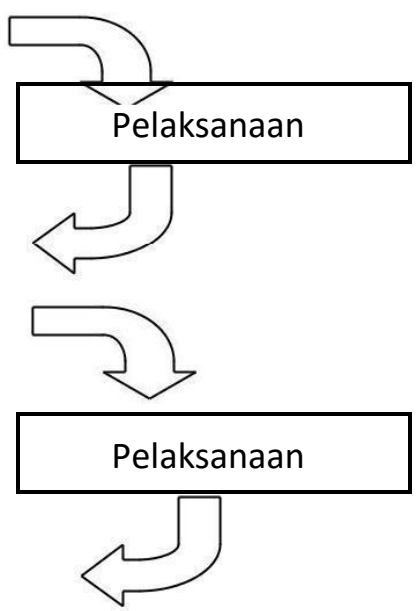

Siklus penelitian diatas, menurut Arikunto (2008:16) tahapan-tahapan dalam setiap siklusnya dapat digambarkan sebagai berikut :

Indikator keberhasilan dalam penelitian tindakan kelas ini adalah 1) 80 $\%$ telah mendapatkan predikat tuntas yang dibuktikan dengan hasil ulangan harian 2) Aktivitas dalam proses pembelajaran meningkat baik yang dibuktikan dengan analisis hasil pengisian angket yang diberikan kepada dengan indikator aktivitas dalam proses pembelajarn tinggi.

\section{HASIL PENELITIAN DAN PEMBAHASAN}

Penelitian Tindakan kelas telah dilaksanakan oleh tim peneliti yang terdiri dari dosen dan guru selama 4 bulan mulai bulan Juli sampai dengan Oktober 2018. Pendekatan pembelajaran yang digunakan adalah pembelajaran melalui pendekatan Adik Simba berbasis gerai informasi untuk meningkatkan aktivitas dan prestasi belajar - Materi dalam penelitian tindakan kelas ini adalah Pancasila Sebagai Dasar Negara Dan Pandangan Hidup Bangsa. 
Kegiatan elaksanaan Penelitian Tindakan Kelas dilaksanakan pada kelas VIII F dengan jumlah 36 orang di SMP Negeri 40 Kota Semarang.

\section{Pelaksanaan Pembelajaran Pada Siklus I}

Pada Siklus I dalam penelitian ini dilaksanakan dalam 3 (tiga) kali pertemuan, dengan 2 (dua) pertemuan

adalah pelaksanaan pembelajaran pendekatan Adik Simba berbasis gerai informasi, dan 1 (satu) pertemuan digunakan untuk evaluasi siklus I. Materi yang diajarkan pada siklus 1 adalah tentang arti dan pentingnya kedudukan dan fungsi Pancasila, makna Pancasila sebagai dasar negara dan pandangan hidup dan arti penting Pancasila sebagai dasar negara dan pandangan hidup bangsa. Secara rinci tahapan pelaksanaan pembelajaran dalam penelitian ini adalah sebagai berikut.

\section{Tahap Perencanaan}

Pada tahap perencanaan ini kegiatan yang ditempuh adalah mendesain Rencana Pelaksanaan Pembelajaran (RPP) menyangkut rencana pelaksanaan pembelajaran melalui pendekatan Adik Simba berbasis gerai informasi pada materi kedudukan dan fungsi Pancasila. Adapun topik/ materi yang dikaji adalah tentang kedudukan dan fungsi Pancasila yang terbagi dalam sub materi yaitu arti dan pentingnya kedudukan dan fungsi Pancasila, makna Pancasila sebagai dasar negara dan pandangan hidup dan arti penting Pancasila sebagai dasar negara dan pandangan hidup bangsa.

Rencana Pelaksanaan

Pembelajaran (RPP) yang dibuat kolaborasi antara guru dan dosen dengan didalamnya didesain dengan pendekatan adik simba berbasis gerai informasi pada materi Pancasila Sebagai Dasar Negara dan Pandangan Hidup Bangsa. Penugasan secara kelompok yang yang diberikan adalah mengkaji tentang makan arti penting kedudukan dan fungsi Pancasila sebagai dasar negara dan pandangan hidup bangsa. Tugas kelompok, hasil observasi pelaksanaan proses pembelajaran, dan tes tertulis secara individual diakhir pelaksanaan siklus 1 ini dijadikan sebagai acuan untuk mengetahui evalusai/hasil dari pembelajaran yang telah dilaksanakan sebagai dasar untuk melaksanakan tindakan berikutnya.

\section{Tahap Pelaksanaan Pembelajaran}

Tahap pelaksanaan pembelajaran adalah tahap implementasi dari Rencana Pelaksanaan Pembelajaran (RPP) yang telah disusun pada tahap perencanaan. Pada tahap pendahuluan dalam proses pembelajaran, dosen menyampaikan tentang tujuan pembelajaran, materi pembelajaran serta pendekatan pembelajaran yang akan diterapkan kepada . Langkah ini diambil supaya mengetahui tujuan yang akan mereka capai serta pendekatan pembelajaran yang akan mereka jalani selama pembelajaran untuk mencapai tujuan tersebut.

Setelah itu, dosen dan guru menyampaikan materi yang berkaitan dengan Pancasila Sebagai Dasar Negara dan Pandangan Hidup Bangsa secara runtut dengan harapan mempunyai pemahaman yang benar serta dasar untuk mengembangkannya serta sebagai bahan untuk menyelesaikan tugas yang dikerjakan melalui diskusi kelompok. 
Setelah Dosen dan guru

memberikan penjelasan awal terkait dengan materi manfaat dan arti penting Pancasila sebagai dasar negara dan pandangan hidup, kemudian diberikan kesempatan untuk menanyakan tentang seputar materi yang telah disampaikan. Beberapa menanyakan tentang apa beda Pancasila sebagai dasar negara dan Pandangan hidup. Guru kemudian memberikan kesempatan kepada lainnya untuk menjawab pertanyaan itu, namun tidak ada yang berani. Guru kemudian menjelaskan secara rinci tentang perbedaan Pancasila sebagai dasar negara dan pandangan hidup. Untuk memperdalam makna Pancasila sebagai dasar negara dan pandangan hidup bangsa, guru kemudian mengelompokkan dalam kelompok kecil yang terdiri dari 4-5 orang. Pembentukan kelompok ini adalah berdasarkan pada hasil tes awal (secara tidak tertulis) yang dilaksanakan guru sebelum kegiatan inti dengan memperhatikan komposisi setiap kelompok terdiri dari yang pandai, sedang, dan kurang. Selanjutnya pelaksanaan kegiatan pembelajaran dalam siklus dalam penelitian ini dilanjutkan dengan tahapan-tahapan dalam pendekatan pembelajaran berikutnya adalah sebagai berikut.

Tahap 1: secara berkelompok diberikan persoalan terkait dengan Kedudukan dan Fungsi Pancasila

Pada tahap ini, setelah mendapatkan penjelasan dari guru, diberikan lembar kerja dari guru yang berisi tentang persoalan - persoalan tentang makna arti penting kedudukan dan fungsi Pancasila dalam kehidupan sehari- hari. secara bekerjasama dalam kelompok mencermati persoalan - persoalan yang terdapat dalam lembar kerja tersebut. Persoalan tersebut harus dibahas dalam kelompok masing-masing dengan setiap individu mempunyai tanggung jawab yang sama dalam pemecahan persoalan tersebut. Hasil kerja kelompok kemudian dituliskan dalam kertas manila yang akan ditempelkan di dinding kelas untuk dipresentasikan.

Dalam tahap ini perserta didik dalam menyelesaikan persoalan yang ada dalam lembar kerja dari guru dianjurkan dan diperkenankan menggunakan berbagai sumber belajar tidak hanya terbatas pada buku peserta didik ataupun buku PPKn yang lainnya. Dalam penyelesaian kerja kelompok, melakukan pembagian tugas tentang aspek-aspek apa yang harus dikerjakan terkait dengan persoalan yang ada dalam lembar kerja . Setiap individu secara bersama-sama dalam satu kelompok memecahkan persoalan yang harus diselesaikan/dikerjakan dimana hasilnya nanti akan dipresentasikan di depan kelompok ynng lain.

\section{Tahap 2: Presentasi kelas}

Tahapan presentasi kelas dilaksanakan pada pertemuan berikutnya. Kegiatan yang dilaksanakan dalam tahap ini, setiap kelompok menempelkan hasil pekerjaannya di dinding ruang kelas. Setiap kelompok kemudian membagi peran dan tanggung jawab tentang siapa nanti yang akan menjelaskan hasil kerja kelompok kepada kelompok lain yang berkunjung di gerai informasi kelompoknya dan siapa saja yang nati akan bertugas mencermati hasil kerja 
kelompok lainnya. Setelah semua kelompok siap, setiap kelompok diberikan kesempatan secara bergilir untuk mencermati hasil kerja kelompok lainnya.

Dalam setiap mempresentasikan hasil kerja kelompoknya di depan kelompok yang lainnya. Hasil presentasi kelompok yang tampil kenudian mendapatkan masukan dari kelompok yang lain.

Tahap 3: Penguatan pembahasan hasil diskusi kelompok.

Tahap penguatan pembahasan hasil diskusi kelompok ini dilakukan guru dengan memberikan penguatan dan penjelasan lebih lanjut tentang perilaku yang sesuai dengan nilai-nilai Pancasila sebagai dasar negara dan pandangan hidup dalam kehidupan keseharian. Penguatan dan penjelasan ini diberikan dalam rangka untuk menyamakan persepsi tentang arti penting Pancasila sebagai dasar negara dan pandangan hidup dalam kehidupan keseharian.

Kegiatan tahap demi tahap pada pelaksanaan pembelajaran di kelas ini kemudian diakhiri dengan guru melakukan tanya jawab dengan dan memberikan penyimpulan tentang materi yang baru dibahas.

\section{Osbsevasi Pembelajaran}

Selama kegiatan tahapan ini, guru yang sekaligus sebagai peneliti dibantu oleh tim observasi melakukan pengamatan terhadap aktivitas dalam mengikuti proses pembelajaran. Dalam melaksanakan observasi tim peneliti menggunakan lembar observasi untuk melihat sejauh mana aktivitas belajar peserta didik meningkat.

\section{Refleksi Pembelajaran Siklus I}

Berdasarkan pelaksanaan observasi dan hasil tes tertulis pada siklus I, maka hasil pelaksanaan pembelajaran pada siklus I dapat diuraikan sebagai berikut.

\section{Aktivitas Dalam Proses Pembelajaran Di Kelas.}

Pada suasana belajar pada siklus I ini masih terlihat pada aktivitas terutama kaitannya dengan kekurangsiapan dalam melaksanakan pendekatan adik simba berbasis gerai informasi pada materi Pancasila Sebagai Dasar Negara dan Pandangan Hidup Bangsa yang diterapkan. Masih ada beberapa yang kurang paham aktivitas apa yang seharusnya mereka lakukan walaupun pada awal kegitan guru sudah menjelaskan tentang model pembelajaran yang akan diterapkan. Hal ini dikarenakan masih tahap penyesuaian dalam kegiatan pembelajaran ini. Tingkat keaktifan dalam mengikuti proses pembelajaran masih menunjukkan pada skala cukup tinggi. Walaupun kelas sudah dinamis dalam arti pembelajaran sudah menekankan keaktivan, namun masih

dijumpai beberapa aktif dalam pembelajaran namun tidak terfolus pada materi pembelajaran.

Dari hasil pengamatan observasi tim peneliti dalam pelaksanaan pembelajaran, tim peneliti menemukan bahwa perhatian masih terpecah selama kegiatan pembelajaran berlangsung. Pada saat guru sedang menjelaskan tentang materi fungsi dan kedudukan Pancasila sebagai dasar negara dan pandangan hidup bangsa terlihat 9 dari 36 (25\%) tidak fokus banhkan sibuk dengan kegiatan 
sendiri seperti melukis/mencoret-coret di kertas gambar, memeinkan ujung jari tanpa memperhatikan guru, meletakkan kepala di atas meja dengan tidak

memperhatikan dan mendengarkan penjelasan guru.

Berkaitan dengan pelaksanaan kerja kelompok dalam penyelesaian lembar kerja yang diberikan guru, yang aktif dalam menyelesaikan tugas secara berkelompok sejumlah 25 dari 36 (69\%) selebihnya aktivitas tidak aktif bahkan ada yang masih bingung dan kemudian tidak mengerjakan soal melainkan asyik dengan aktivitas lain (acuh tak acuh, diam,

menggambar, mencoret-coret kertas kososng, mengamati temannya bekerja, ataupun mengganggu temannya yang sibuk bekerja ) sebanyak 11 dari 36 (31\%).

Perkembangan individu terkait dengan nilai individual secara keseluruhan sudah menunjukkan hasil yang baik yaitu $79 \%$ dari $80 \%$ yang ditetapkan. Namun masih ada beberapa individu yang belum mencapai perkembangan yang diharapkan. Berkaitan dengan indikator keberhasilan pencapaian prestasi hasil belajar menunjukkan bahwa dengan Kriteria Ketuntasan Minimal 70, masih terdapat 7 yang belum tuntas. Hal ini menunjukkan bahwa ketercapaian $80 \%$ tuntas dalam pembelajaran masih belum tercapai.

Tabel 1

Hasil Evaluasi Siklus 1

\begin{tabular}{cccc}
\hline No & Rentang Nilai & Jumlah & Prosentase (\%) \\
\hline $\mathbf{1}$ & $\mathbf{4 0}-\mathbf{4 9}$ & $\mathbf{1}$ & $\mathbf{3}$ \\
2 & $\mathbf{5 0}-\mathbf{5 9}$ & $\mathbf{1}$ & 3 \\
3 & $\mathbf{6 0}-\mathbf{6 9}$ & $\mathbf{4}$ & 11 \\
4 & $\mathbf{7 0}-\mathbf{7 9}$ & $\mathbf{1 7}$ & 47 \\
5 & $\mathbf{8 0}-\mathbf{8 9}$ & $\mathbf{1 2}$ & 33 \\
5 & $\mathbf{9 0}-\mathbf{1 0 0}$ & $\mathbf{1}$ & 3 \\
\hline & Jumlah & 36 & 100 \\
\hline
\end{tabular}

Berkaitan dengan tahapan presentasi kelompok dan presentasi kelas, pelaksanaan proses presentasi sudah berjalan dengan baik dan serius, namun kesimpulan yang diambil dari penyelesaian persoalan yang terkait dengan fungsi dan kedudukan Pancasila sebagai dasar negara dan pandangan hidup masih jauh dari kompetensi yang diinginkan. Beberapa terlihat aktif dalam kegiatan presentasi baik dari mulai menyampaikan materi sampai pemberian tanggapan, namun ada beberapa pesefta didik yang terlihat hanya tidak serius dalam mengikuti presentasi kelas, hal ini terlihat dari aktifitas yang dilakukannya (diam, bingung, berbicara dengan temannya sendiri, main sendiri, tiduran di kelas).

Secara umum berdasarkan temuan hasil observasi dilapangan tentang pelaksanaan pembelajaran diskusi/kerja kelompok dapat disimpulkan bahwa belum menunjukkan pada tingkat yang baik. Hal ini dibuktikan dari : 1) Tingkat

keaktifan dalam mengikuti proses pembelajaran masih menunjukkan pada skala cukup tinggi. Walaupun kelas sudah 
dinamis dalam arti pembelajaran sudah menekankan keaktivan, namun masih

dijumpai beberapa aktif dalam pembelajaran namun tidak terfolus pada materi pembelajaran. 2) 31\% ( 11 dari 36 ) aktivitas tidak aktif bahkan ada yang masih bingung dan kemudian tidak mengerjakan soal melainkan asyik dengan aktivitas lain (acuh tak acuh, diam,

menggambar, mencoret-coret kertas kososng, mengamati temannya bekerja, ataupun mengganggu temannya yang sibuk bekerja ).3) Ketuntasan belajar belum mencapai $80 \%$.

Berdasarkan hal tersebut dampak aktivitas dan prestasi belum terlihat sesuai dengan harapan yaitu tercapainya indikator yang telah ditetapkan. Melihat kondisi tersebut, peneliti kemudian merasa perlu untuk melanjutkan penelitian ini ke Siklus II.

\section{Pelaksanaan Pembelajaran Pada Siklus II}

Tahap pembelajaran pada siklus ke dua ini dilaksanakan sebanyak 3 kali pertemuan dengan perincian 2 kali tatap muka dan satu kali tes tertulis. Berdasarkan hasil evaluasi dari siklus 1, maka pelaksanaan siklus 2 ini dilaksnakan dengan memperhatikan kekurangan pada siklus 1. Perubahan yang dilaksanakan antara lain dengan memberikan pemahaman tentang proses pembelajaran yang akan dilakukan kepada peseta didik, pemberitahuan tentang proses penilaian pembelajaranh yang menekankan pada aktivitas kegiatan pembelajaran pada .

Materi yang akan diajarkan pada siklus 2 ini adalah perilaku yang sesuai dengan nilai-nilai Pancasila sebagai dasar negara dan pandangan hidup bangsa dalam kehidupan sehari-hari.
Refleksi Pembelajaran Siklus II Berdasarkan pelaksanaan observasi dan hasil tes tertulis pada siklus II, maka hasil pelaksanaan pembelajaran pada siklus II dapat diuraikan sebagai berikut.

\section{Aktivitas Dalam Proses Pembelajaran Di Kelas.}

Pada suasana belajar pada siklus II ini terlihat pada aktivitas dalam pembelajaran dengan menggunakan pendekatan adik simba berbasis gerai informasi pada materi perilaku yang sesuai dengan nilai-nilai Pancasila sebagai dasar negara dan pandangan hidup bangsa dalam kehidupan sehari-hari yang

diterapkan mengalami peningkatan. Walaupun masih ada beberapa yang kurang aktivitas pembelajarannya namun jumlahnya sudah berkurang. Hal ini dikarenakan sudah mulai dapat penyesuaian beraktifitas kegiatan pembelajaran adik sismba berbasis gerai informasi ini. Tingkat keaktifan dalam mengikuti proses pembelajaran sudah menunjukkan pada skala tinggi. Suasana kelas sudah terlihat dinamis dalam arti

pembelajaran sudah menekankan keaktivan dan aktif dalam pembelajaran.

Dari hasil pengamatan observasi tim peneliti dalam pelaksanaan pembelajaran, tim peneliti menemukan bahwa perhatian sudah menunjukkan perkembangan menuju ke arah lebih baik selama kegiatan pembelajaran berlangsung. Pada saat guru sedang menjelaskan tentang materi perilaku yang sesuai dengan nilai-nilai Pancasila sebagai dasar negara dan pandangan hidup bangsa dalam kehidupan sehari-hari terlihat 4 dari $36(11 \%)$ tidak fokus banhkan sibuk dengan kegiatan sendiri seperti melukis/mencoret-coret di 
kertas gambar, memeinkan ujung jari tanpa memperhatikan guru. Hal ini menunjukkan berarti ada peningkatan jumlah yang aktif dalam pembelajaran dengan pendekatan adik simba berbasis gerai informasi.

Berkaitan dengan pelaksanaan kerja kelompok dalam penyelesaian lembar kerja yang diberikan guru, yang aktif dalam menyelesaikan tugas secara berkelompok sejumlah 30 dari 36 (83\%) selebihnya aktivitas tidak aktif bahkan ada yang masih bingung dan kemudian tidak mengerjakan soal melainkan asyik dengan aktivitas lain (diam, mengamati temannya bekerja, ataupun mengganggu temannya yang sibuk bekerja ) sebanyak 6 dari $36(17 \%)$.

Perkembangan individu terkait dengan nilai individual secara keseluruhan sudah menunjukkan hasil yang baik yaitu $97 \%$ dari $80 \%$ yang ditetapkan. Namun masih ada satu individu yang belum mencapai perkembangan yang diharapkan. Berkaitan dengan indikator keberhasilan pencapaian prestasi hasil belajar menunjukkan bahwa dengan Kriteria Ketuntasan Minimal 70, masih terdapat 7 yang belum tuntas. Hal ini menunjukkan bahwa ketercapaian $97 \%$ tuntas dalam pembelajaran masih belum tercapai.

Tabel 1

Hasil Evaluasi Siklus 1

\begin{tabular}{cccc}
\hline & Rentang Nilai & Jumlah & Prosentase (\%) \\
\hline $\mathbf{1}$ & $\mathbf{4 0 - 4 9}$ & $\mathbf{0}$ & $\mathbf{0}$ \\
2 & $\mathbf{5 0 - 5 9}$ & $\mathbf{0}$ & 0 \\
3 & $\mathbf{6 0}-\mathbf{6 9}$ & $\mathbf{1}$ & 3 \\
4 & $\mathbf{7 0}-\mathbf{7 9}$ & $\mathbf{2 1}$ & 58 \\
5 & $\mathbf{8 0}-\mathbf{8 9}$ & $\mathbf{1 2}$ & 33 \\
5 & $\mathbf{9 0}-\mathbf{1 0 0}$ & $\mathbf{2}$ & 6 \\
\hline & Jumlah & 36 & 100 \\
\hline
\end{tabular}

Berkaitan dengan tahapan presentasi kelompok dan presentasi kelas, pelaksanaan proses presentasi sudah berjalan dengan baik dan serius,. Penyelesaian persoalan yang terkait dengan perilaku yang sesuai dengan nilainilai Pancasila sebagai dasar negara dan pandangan hidup bangsa dalam kehidupan sehari-hari sudah sesuai dengan harapan yang telah ditetapkan. Sebagian besar terlihat aktif dalam kegiatan presentasi baik dari mulai menyampaikan materi sampai pemberian tanggapan, walaupun ada beberapa yang terlihat tidak serius dalam mengikuti presentasi kelas, hal ini terlihat dari aktifitas yang dilakukannya (diam, berbicara dengan temannya sendiri).

Secara umum berdasarkan temuan hasil observasi dilapangan tentang pelaksanaan pembelajaran diskusi/kerja kelompok dapat disimpulkan bahwa belum menunjukkan pada tingkat yang baik. Hal ini dibuktikan dari : 1) Tingkat keaktifan dalam mengikuti proses pembelajaran masih menunjukkan pada skala sudah tinggi. Kelas sudah dinamis dalam arti pembelajaran sudah 
menekankan keaktivan. Sebagian besar peserta didik sudah aktif dalam pembelajaran walaupun masih dijumpai sebagian kecil aktif dalam pembelajaran namun tidak fokus pada materi pembelajaran. 2) 83\% ( 30 dari 36 ) sebagian besar aktif dalam menyelesaikan tugas secara berkelompok selebihnya aktivitas tidak aktif bahkan ada yang masih bingung dan kemudian tidak mengerjakan soal melainkan asyik dengan aktivitas lain (diam, mengamati temannya bekerja, ataupun mengganggu temannya yang sibuk bekerja ) sebanyak 6 dari 36

(17\%). 3) Ketuntasan belajar sudah mencapai $97 \%$ artinya indikator kinerja penelitiansudah tercapai.

Berdasarkan hal tersebut dampak aktivitas dan prestasi sudah terlihat sesuai dengan harapan yaitu tercapainya indikator yang telah ditetapkan. Melihat kondisi tersebut, peneliti kemudian merasa penelitian tindakan kelas tersebut sudah terpenuhi.

Menurut Wina Sanjaya (2012:9) terdapat lima keputusan yang harus dilakukan guru untuk menjamin kualitas pembelajaran. Pertama, setiap guru harus memutuskan tetang apa yang harus dipahami oleh seorang peserta didik yang akan diajarnya. Kedua, menentukan tingkah laku bagaimana yang yang harus dilakukan peserta didik untuk menjamin pemahaman bahan ajar. Ketiga, menentukan strategi yang dapat memberikan pengalaman belajar sesuai dengan gaya belajar peserta didik. Keempat, setiap guru harus menentukan setiap pengaruh yang muncul sehubungan dengan strategi yang diterapkan. Kelima, setiap guru juga harus menentukan bagaimana cara menilai pengaruh atas dampak serta menilai hasil yang dicapai setiap peserta didik.

Kondisi pembelajaran dimana peserta didik menunjukkan kecenderungan sikap tidak fokus, acuh tak acuh, tidak ikut terlibat dalam aktivitas pembelajaran pasti terjadi dalam proses pembelajaran di kelas. Guru diharapkan dapat mendesain pembelajaran dengan pelibatan keaktifan peserta didik. Salah satu pendekatan pembelajaran yang dapat digunakan adalah pembelajaran colaboratif.

Peningkatan minat dan aktivitas belajar peserta didik dapat dilaksanakan melalui kegiatn literasi. Strategi literasi dalam pembelajaran adalah untuk membangun pemahaman, keterampilan menulis, dan keterampilan komunikasi secara menyeluruh.Tiga hal ini akan bermuara pada pengembangan karakter dan keterampilan berpikir tingkat tinggi. Salah satu strategi pembelajaran yang dapat digunakan dalam literasi adalah Adik Simba. Adik simba adalah

pendekatan pembelajaran dimana diberikan pengalaman untuk mengidentifikasi informasi penting dengan menggunakan kata tanya. Kata tanya yang digunakan antara lain siapa, apa, kapan, dimana, mengapa, bagaimana. Pada pendekatan pembelajaran adik simba, diminta untuk menganalisis materi pembelajaran dengan kata tanya $5 \mathrm{~W} 1 \mathrm{H}$ (What, Who, Where, When, Why, How).

Hal ini sejalan dengan hasil penelitian yang peneliti dapatkan dalam pelaksanaan penelitian tindakan kelas ini. Hasil penelitian dengan pembelajaran kolaboratif berbasis literasi melalui 
pendekatan adik simba menunjukkan Tingkat keaktifan dalam mengikuti proses pembelajaran masih menunjukkan pada skala sudah tinggi. Sebagian besar aktif dalam menyelesaikan tugas secara berkelompok . Ketuntasan belajar sudah mencapai $97 \%$ artinya indikator kinerja penelitiansudah tercapai. Hal ini berarti bahwa pembelajaran adik simba berbasis gerai informasi dapat meningkatkan aktivitas belajar peserta didik dan prestasi belajar peserta didik.

\section{SIMPULAN}

Berdasarkan hasil penelitian dan pembahasan dalam penelitian ini, maka dapat disimpulkan. 1) Pelaksanaan pembelajaran dengan pendekatan adik simba berbasis gerai informasi pada materi Pancasila Sebagai Dasar Negara

dan Pandangan Hidup Bangsa dilaksanakan melalui 2 siklus dan dapat meningkatkan aktivitas belajar dan prestasi hasil belajar Bangsa di kelas VIII F Sekolah Menengah Pertama Negeri 40 Kota Semarang. 2) Dampak peningkatan aktivitas belajar dan prestasi hasil belajar dalam pembelajaran PPKn dengan pendekatan adik simba berbasis gerai informasi pada materi Pancasila Sebagai Dasar Negara dan Pandangan Hidup Bangsa ditunjukkan dengan a)

Tingkat keaktifan dalam mengikuti proses pembelajaran masih menunjukkan pada skala sudah tinggi. Kelas sudah dinamis dalam arti pembelajaran sudah menekankan keaktivan. Sebagian besar peserta didik sudah aktif dalam pembelajaran walaupun masih dijumpai sebagian kecil aktif dalam pembelajaran namun tidak fokus pada materi pembelajaran. b) $83 \%$ ( 30 dari 36 ) sebagian besar aktif dalam menyelesaikan tugas secara berkelompok selebihnya aktivitas tidak aktif bahkan ada yang masih bingung dan kemudian tidak mengerjakan soal melainkan asyik dengan aktivitas lain (diam, mengamati temannya bekerja, ataupun mengganggu temannya yang sibuk bekerja ) sebanyak 6 dari 36 (17\%). 3) Ketuntasan belajar sudah mencapai $97 \%$ artinya indikator kinerja penelitiansudah tercapai.

\section{DAFTAR PUSTAKA}

Anita Lie. 2002. Cooperatif Learning Mempraktikkan Cooperative Learning di Ruang-Ruang Kelas. Jakarta:Grasindo.

Cooper, James M. 1990. Classroom Teaching Skill. Canada : DC. Health and Company

Driscoll J (2000) Practising clinical supervision. Edinburgh: Balliere Tindall

Martinis, Yamin. 2011. Paradigma Baru Pembelajaran. Jakarta : Gaung Persada Press Jakarta.

Roblyer, M. D., Edwards, J., \& Havriluk, M. A.(1997).Integrating

educational technology into teaching. Upper Saddle River, NJ: Prentice-Hall.

Slameto. 1998. Evaluasi Pendidikan. Jakarta: Bina Aksara.

Sudjana, Nana. 1991. Dasar-dasar Proses Belajar Mengajar. Bandung : Sinar Baru.

Sanjaya, Wina. 2012. Strategi Pembelajaran Berorientasi Standar Proses Pendidikan. Jakarta: Kencana Prenada M 
